\title{
The Effects of the Opportunity Principle on the Attorney General's Office's Deponerring Implementation
}

\section{Romula Hasonangan ${ }^{1}$ Hari Purwadi ${ }^{2}$ Andina Elok Puri Maharani ${ }^{3}$ \\ 1.2.3. Faculty of Law, Universitas Sebelas Maret, Surakarta, Indonesia.}

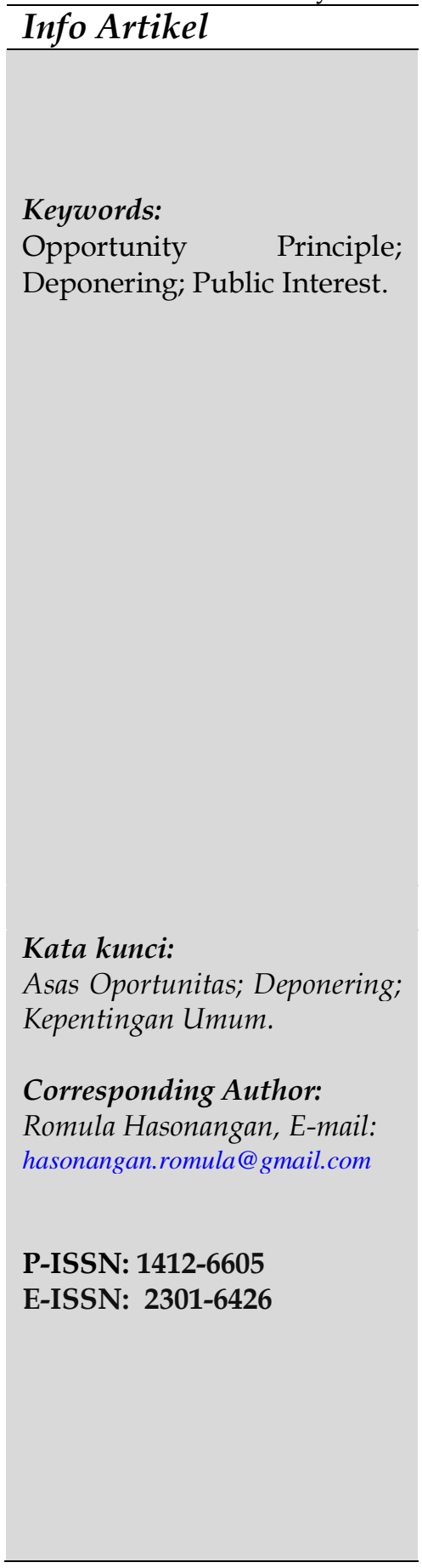

\begin{abstract}
This study aims to analyze the implications of the principle of opportunity for implementing depowering in the Attorney General's Office. This is normative legal research, with secondary data in primary, secondary, and tertiary legal materials. The results showed that implementing depowering as part of the principle of opportunity was not optimal and practical. The causative factors were. First, the legal material was still ambiguous regarding the definition of public interest as the basis for implementing depowering. Secondly, the understanding of the prosecutor's office on the principle of opportunity was not coherent with the principle of equality before the law by the apparatus. Third, the factor of the legal culture of the community whose trust is still deficient in the implementation of the principle of opportunity by the Prosecutor's Office.
\end{abstract}

\footnotetext{
Abstrak

Penelitian ini bertujuan untuk menganalisa implikasi asas oportunitas terhadap pelaksanaan deponerring di Kejaksaan. Penelitian ini merupakan penelitian hukum normatif, dengan data sekunder berupa bahan hukum primer, sekunder dan tersier. Hasil penelitian menunjukkan bahwa pelaksanaan deponering sebagai bagian dari asas oportunitas belum optimal dan efektif, faktor penyebabnya adalah pertama, materi hukumnya masih ambigu terkait definisi kepentingan umum sebagai dasar pelaksanaan deponering, kedua, pemahaman aparat kejaksanaan terhadap asas oportunitas yang belum coherensi dengan asas equality before the law oleh aparat, ketiga, faktor budaya hukum masyarakat yang kepercayaannya masih sangat rendahnya terhadap pelaksanaan asas oportunitas oleh Kejaksaan.
} 


\section{Introduction}

Law enforcement enforces the law by enforcing it and resolving disputes through courts, arbitration, and other conflict resolution mechanisms. Law enforcement can also be defined as legal activity used to regulate and bind legal subjects. Included in this is the enforcement of any violations or irregularities relating to laws and regulations through the criminal justice process, which involves the roles of police, prosecutors, advocates or lawyers, and judicial authorities. Prosecutors must undertake research, evaluate, and delve deeper while addressing a case. ${ }^{1}$

In Indonesia, the prosecution system is regulated by Law No. 16 of 2004 on the Prosecutor's Office, which is founded on the principle of legality and focuses on opportunity. The public prosecutor is required to sue someone accused of committing a crime in accordance with applicable criminal law rules. It adheres to the legal principle. Meanwhile, under the principle of opportunity, the public prosecutor is not required to prosecute someone who performs a criminal act if, in his judgment, prosecution would jeopardize the public interest; hence, a person who commits a crime cannot be prosecuted in the public interest. ${ }^{2}$

This provision is consistent with Article 140(2) letter of the Criminal Procedure Code (KUHAP), which provides that the Prosecutor's Office has the ability to halt prosecutions throughout the prosecution stage. It must be understood alternately, not cumulatively, based on this interpretation. Even Article $35 \mathrm{C}$ of the Republic of Indonesia's Law No. 16 of 2004 on the Attorney General's Office provides that the Attorney General has the ability to override cases in the public interest. According to the explanation of Law No. 16 of 2004 about the Prosecutor's Office, setting aside an issue is an application of the concept of opportunity, which the Attorney General may only do after considering the ideas and opinions of the relevant state power agency. ${ }^{3}$

This provision, however, contradicts the sense of Article 27(2) of the 1945 Constitution, which stipulates that all people are equal before the law. Article 35 letter c of Law No. 16 of 2004 governing the Prosecutor's Office may be declared invalid. Regulations governing the doctrine of opportunity are critical in the Indonesian criminal justice system, given the theory's potential for abuse. As one of the prosecutor's powers, the concept of chance has not been employed

\footnotetext{
1 Jared M. Ellison and Randy Gainey, 'An Opportunity Model of Safety Risks among Jail Officers', $\begin{array}{llllll}\text { Journal of Criminal Justice, } & \text { 66.October } 2019 & \text { (2020), } & 101632\end{array}$ <https://doi.org/10.1016/j.jcrimjus.2019.101632>.

${ }^{2}$ Moh Iqra, Syabani Korompot, and Al-fatih David, 'The Principle of Equality Before the Law in Indonesian Corruption Case : Is It Relevant?', Journal of Human Rights, Culture and Legal System, 1.3 (2021), 135-46.

${ }^{3}$ Arif Purnama Oktora and Hilaire Tegnan, 'Strategy for Implementing Operations to Handle the Crime of Narcotics', Journal of Human Rights, Culture and Legal System, 1.3 (2021), 201-13.
} 
effectively, specifically for the public good, there is still a reality that it is used for claims other than those covered by the law. ${ }^{4}$

For example, first, the case of Abraham Samad, who is suspected of falsifying documents as referred to in Article 263 paragraph (1) in conjunction with Article 53 paragraph (1) to 1 of the Criminal Code, Article 264 paragraph (1) in conjunction with Article 55 paragraph (1) to 1 of the Criminal Code, and abuse of power under the Corruption Eradication Commission (KPK) Law. Second, the case of Bambang Widjayanto, who allegedly influenced witnesses to give false statements during the trial of the West Waringin City Election dispute in Central Kalimantan at the Constitutional Court in 2010. The case was depowered by the Attorney General, even though the decision did not reflect the principle of the community's public interest, thus weakening the public interest. The legal system, namely the principle of equality before the law and legal certainty. ${ }^{5}$

However, the Attorney General's Office showed a different attitude in the decision of the Kepanjen District Court Number 01/Pid.SusAnak/2020/PN.KPN. The defendant tortured to death Misnan, a robber who tried to confiscate his motorbike and cell phone. Minsan also attempted to rape a friend of Defendant, so Defendant fought back by stabbing Misnan to death as a form of self-protection due to Misnan's attempted crime against Defendant. The defendant was sentenced to Article 351 paragraph (3) of the Criminal Procedure Code and sentenced to imprisonment for 1 (one) year. This case should receive a depowering decision because it is a case that causes turmoil in society due to a person being convicted for defending himself and others. In addition to this case, the prosecutor's office was also reluctant to issue a deponiring decision, in the case of Grandma named Minah (55) stealing three cocoa pods from a plantation owned by PT Rumpun Sari Antan (RSA), which violated Article 362 of the Criminal Code and forced her to be sentenced to 1 month and 15 days in prison with probation. Three months; in January 2010, a mother named Manish and her two children and a nephew, who were deemed to have stolen kapok fruit in violation of Article 363 of the Criminal Code, were sentenced to 1 year in prison with four months probation. ${ }^{6}$

The examples above show the ineffectiveness of the role of the prosecutor's office in its authority, namely depowering as the embodiment of the principle of

${ }^{4}$ Zhicheng Wang, Lisa Bero, and Quinn Grundy, 'Understanding Professional Stakeholders' Active Resistance to Guideline Implementation: The Case of Canadian Breast Screening Guidelines', Social Science and Medicine, 269.December $2020 \quad$ (2021) <https://doi.org/10.1016/j.socscimed.2020.113586>.

5 John A. Shjarback and Justin Nix, 'Considering Violence against Police by Citizen Race/Ethnicity to Contextualize Representation in Officer-Involved Shootings', Journal of Criminal Justice, 66.October 2019 (2020), 101653 <https:/ / doi.org/10.1016/j.jcrimjus.2019.101653>.

${ }^{6}$ Ieke de Vries and others, 'Crime Frames and Gender Differences in the Activation of Crime Concern and Crime Responses', Journal of Criminal Justice, 66.November 2019 (2020), 101651 <https://doi.org/10.1016/j.jcrimjus.2019.101651>. 
opportunity, which is marked by the lack of implementation of the principle of opportunity in cases that are communal rather than non-communal. The situation that should be carried out by deponering based on the public interest is not carried out and vice versa. In addition to the government's will (government will), this occurs due to the unclear concept of "public interest" in Law Number 16 of 2004 concerning the Prosecutor's Office. ${ }^{7}$

However, the guidelines for implementing the Criminal Procedure Code provide criteria that the term in the public interest in applying the principle of opportunity is based on the interests of the nation, the state, and the wider community and not for individual interests. Still, the explanation regarding the clauses related to the interests of the government and the state and the interests of the wider community is not explained explicitly. It has a broad scope in interpreting these interests so that it can become a space for the Attorney General to be prone to abusing this authority. At the same time, it also shows that there is no legal certainty in the article, especially in its implementation.

\section{Results and Discussion}

\section{Synchronization of Regulatory Substance in Implementing the Principle of Opportunity by the Attorney General's Office.}

Major synchronization is (significant synchronization), specifically vertical and horizontal alignment of regulation material pertaining to the Attorney General's Office's implementation of the principle of opportunity. Indonesia conforms to the legal fiction principle, which presumes that everyone is aware of a rule..$^{8} \mathrm{~A}$ law is formed or enacted by the government, and all Indonesian citizens are automatically required to obey and apply it, as the law is binding on all Indonesian citizens. In an ideal world, regulation would reflect the community's demands. While the government may have enacted a number of rules or laws in response to a criminal conduct, no law regulates the crime. ${ }^{9}$

The question that emerges is when the Indonesian government takes sides and considers the predicament of the people. This is demonstrated in the creation of one of the laws, notably the labor legislation. It is evident

\footnotetext{
${ }^{7}$ Philipp Harms and Jakob Schwab, 'Depression of the Deprived or Eroding Enthusiasm of the Elites: What Has Shifted the Support for International Trade?', European Journal of Political Economy, 64.November 2019 (2020), 101901 <https:/ / doi.org/10.1016/j.ejpoleco.2020.101901>. 8 Utkarsh K Mishra and Abhishek Negi, 'Should Trade Remedies Be Eliminated from WTO : A Response to Tania Voon', Journal of Human Rights, Culture and Legal System, 1.3 (2021), 194-200. 9 Ratna Sofiana, Satria Utama, and Abdur Rohim C, 'The Problems of Halal Certification Regarding Consumer Protection in Malaysia and Indonesia', Journal of Human Rights, Culture and Legal System, 1.3 (2021), 180-93 <https:/ / doi.org/https:// doi.org/10.53955/jhcls.v1i3.16>.
} 
from this law that the laws enacted favor entrepreneurs or factory owners. ${ }^{10}$ This is an issue that needs to be addressed and corrected. Because if this trend continues, it is certain that there will be no effective coordination and synchronization between the criminal justice system's subsystems. It is not a medication or an antidote that can bring about community justice. Rather than that, it causes those in charge of the law to lose their sense of fairness. This may have an effect on the public's loss of trust in these law-making governments. Along with remaining in sync with the sub-systems involved in the synchronization of the substance field, this sub-system must also maintain communication with other sub-systems, specifically the structural sub-system. ${ }^{11}$

Concerning the application of deponering, it is a critical component of the Attorney General's Office's principle of opportunity. In this instance, the commission is limited to the Attorney General's office. The discretion is a policy that is exclusively motivated by justice considerations and is not constrained by the provisions of the law. The principle of opportunity is the prosecutor's jurisdiction, which is limited to dismissing cases in the public good. The Criminal Procedure Code does not define opportunity clearly. Nonetheless, it is contained in Article 35 letter (c) of Law No. 16 of 2004 governing the Attorney General's Office of the Republic of Indonesia, which indicates that the Attorney General has the ability to override situations involving the public interest. 12

However, even though the opportunity principle is not explicitly controlled in the Criminal Procedure Code, as it is in Law Number 16 of 2004, the Criminal Procedure Code gives an opportunity to apply it. Articles on exceptions to the rule are not dealt with in isolation. Nonetheless, they are dispersed throughout the regulations pertaining to confiscated property and pre-trial Paragraph 1 of Article 46 (c) According to the Criminal Procedure Code, the case is adjudicated in the public interest, and so on.

${ }^{10}$ Resti Dian and Suviwat Jenvitchuwong, 'Implementation of Halal Product Assurance in the Pharmaceutical Sector in Indonesia', Journal of Human Rights, Culture and Legal System, 1.3 (2021), 164-79 <https://doi.org/https://doi.org/10.53955/jhcls.v1i3.19>.

${ }^{11}$ Eric J. Connolly and others, 'Do Developmental Changes in Impulsivity and Sensation Seeking Uniquely Predict Violent Victimization? A Test of the Dual Systems Model', Journal of Criminal Justice, 66.October 2019 (2020), 101639 <https://doi.org/10.1016/j.jcrimjus.2019.101639>.

12 Simon McNamara, Aki Tsuchiya, and John Holmes, 'Does the UK-Public's Aversion to Inequalities in Health Differ by Group-Labelling and Health-Gain Type? A Choice-Experiment', $\begin{array}{lllll}\text { Social Science and Medicine, 269.December } 2020 & \text { (2021), } & 113573\end{array}$ <https://doi.org/10.1016/j.socscimed.2020.113573>. 
There is no justification in this provision for the waiver of the case, except for confiscated objects. ${ }^{13}$

However, the language of Article 77 of the Criminal Procedure Code has an appropriate explanation of the Attorney General's authority to sideline cases. Article 77 of the Criminal Procedure Code is clarified as follows: "Termination of prosecution" does not include the Attorney General's authority to set aside cases in the public interest. According to the Criminal Procedure Code's interpretation of Article 77 and the manual for implementing the Criminal Procedure Code, the Criminal Procedure Code recognizes the existence of the principle of opportunity. ${ }^{14}$

In formal criminal law, the notion of opportunity is enshrined in Article 35 (c) of the Prosecutor's Law. To be specific, the Attorney General has the authority to dismiss cases that are not in the public interest. In simple terms, the term "public interest" refers to a variety of people's purposes, requirements, or interests, as well as general aims. Of course, linguistics cannot be utilized to interpret the term "public interest" as employed in Article 35. (c). The public interest has been extensively governed since the independence era by a variety of laws and regulations, the formulations of which vary. Due to the complete concept of the public interest, the term "public interest" has a broad definition. Activities for the public interest can encompass a wide variety of activities. ${ }^{15}$

Setting aside cases or deponering as an application of the principle of opportunity is critical in the Indonesian criminal justice system so that the deponering arrangement does not become a rule that is abused by criminal justice agencies or institutions, particularly the prosecutor's office, which has the authority to conduct deponering. As a result, it is vital to harmonize the concept of public interest. In various disciplines, the definition of public interest can be found in property acquisition. Land acquisition is governed by Law No. 2 of 2012 on Land Procurement for Public Development. ${ }^{16}$

\footnotetext{
${ }^{13}$ Jason A. Ford and others, 'Educational Attainment and Prescription Drug Misuse: The Importance of Push and Pull Factors for Dropping Out', Journal of Criminal Justice, 66.October 2019 (2020), $101636<$ https://doi.org/10.1016/j.jcrimjus.2019.101636>.

${ }^{14}$ Niklas Potrafke, Marcus Rösch, and Heinrich Ursprung, 'Election Systems, the "Beauty Premium" in Politics, and the Beauty of Dissent', European Journal of Political Economy, 64.October 2019 (2020) <https://doi.org/10.1016/j.ejpoleco.2020.101900>.

15 Abhery Das and others, 'Emergency Department Visits for Depression Following Police Killings of Unarmed African Americans', Social Science and Medicine, 269.November 2020 (2021), 113561 <https://doi.org/10.1016/j.socscimed.2020.113561>.

${ }^{16}$ Corinne H. Rocca and others, 'Emotions over Five Years after Denial of Abortion in the United States: Contextualizing the Effects of Abortion Denial on Women's Health and Lives', Social $\begin{array}{lllll}\text { Science and } & \text { Medicine, 269.November } 2020 \quad \text { (2020), } & 113567\end{array}$ <https://doi.org/10.1016/j.socscimed.2020.113567>.
} 
The law defines public interest as the interests of the majority of society's levels, the interests of the nation, state, and organization, which must be realized by the government and utilized to the greatest extent possible for the people's welfare. However, the definition provided in Article 1 paragraph 6 of Law No. 2 of 2012 remains imprecise (vague norm). The law makes no specific reference to enumerative development initiatives in the public interest. Different interpretations of the public interest exist in its execution. It is critical to limit the public interest criterion. There are no other interpretations that allow a clear distinction between development for the public good and development solely for profit to be made in its implementation. ${ }^{17}$

Similarly, in Article 35 letter c of Law No. 16 of 2004 governing the Prosecutor's Office, "public interest" refers to the nation's and state's or community's interests. The concept of interest in the Prosecutor's Law remains ambiguous, as there are no limits to the public interest requirements. Due to the vagueness of the public interest goal, it may be difficult to use deponering as an opportunity principle in circumstances requiring deponering. Thus, unifying the notion and definition of the public interest is critical for establishing legal certainty in instances where the direction of opportunity conflicts with the principle of legal certainty. ${ }^{18}$

Because the current definition of public interest does not explain the formulation, aim, or boundaries of the public interest, the Prosecutor's Law's public interest provisions should be examined. The definition of public interest must be reaffirmed, along with an explanation of the public interest's criteria and limitations, as well as the implications for the regulation of public interest as a condition for the Attorney General to use deponering, in order to avoid multiple interpretations and misinterpretations by other state institutions. Then it has repercussions for justice seekers, specifically the deponed party, because the suspect's position is unclear, whether he immediately vanishes or remains a suspect. ${ }^{19}$

17 Lavanya Vijayasingham, Uma Jogulu, and Pascale Allotey, 'Ethics of Care and Selective Organisational Caregiving by Private Employers for Employees with Chronic Illness in a MiddleIncome Country', Social Science and Medicine, 269.December 2020 (2021), 113608 <https://doi.org/10.1016/j.socscimed.2020.113608>.

${ }^{18}$ Jonas Fooken and Linh K. Vo, 'Exploring the Macroeconomic and Socioeconomic Determinants of Simultaneous over and Undernutrition in Asia: An Analysis of Stunted Child - Overweight Mother Households', Social Science and Medicine, 269.December 2020 (2021), 113570 $<$ https://doi.org/10.1016/j.socscimed.2020.113570>.

19 Dzhansarayeva Rima and others, 'Exploring the Potential Association between Gang Membership and Health Outcomes in a Longitudinal Sample of Youth and Young Adults', Journal of Criminal Justice, 66.May 2019 (2020), 101629 <https:/ / doi.org/10.1016/j.jcrimjus.2019.101629>. 
Interest is defined as an individual or collective demand that is expected to be met. In essence, it contains an authority to carry it out that is guaranteed and protected by law. Numerous interests, both individual and collective, must be honored and safeguarded in society. It is normal for each individual or group to anticipate or demand that their interests be protected and satisfied, even if it is difficult to do so for all. Simultaneously, given these interests, many also conflict, despite their numerous distinctions. ${ }^{20}$

\section{Structural Synchronization in Implementing the Principle of Opportunity by the Attorney General's Office.}

Structural synchronization (structural synchronization) refers to the synchronization and harmony of law enforcement agencies' relationships. The structural area is subdivided into the following subsystems within criminal justice. This is why this system must be completely synced with the criminal justice system's sub-system and with the structural field's subsystem as well. In this structural field, the sub-system is the sub-system that becomes the perpetrator or takes action to bring about justice. This structural field has several other subs, including the Police, the Prosecutor's Office, the Court, and the Correctional Institution (Penitentiary). This structural area subsystem serves as the instrument and implementer for any regulatory violations or acts that violate applicable legislation. ${ }^{21}$

As a result, a proper relationship must be established between Synchronization in the Substance field and Synchronization. Thus, if the government issues a regulation, it should be consistent with the work required of law enforcers in the structural sub-system. However, what occurs in the implementation and prosecution of criminals or those who breach the applicable laws and regulations in this structural field frequently violates the applicable laws. Occasionally, what is done with what is regulated by law is not as it should be. ${ }^{22}$

Occasionally, the converse occurs, namely the alignment of applicable laws with law enforcement agents seeking to establish justice in society. One example of how regulations or norms in force are out of step with what law enforcers do is the Criminal Procedure Code's non-implementation in law enforcement authorities or the structural sector. This may be seen in a

${ }^{20}$ Brian J. Hall and others, 'Fast Food Restaurant Density and Weight Status: A Spatial Analysis among Filipina Migrant Workers in Macao (SAR), People's Republic of China', Social Science and Medicine, 269.July 2020 (2021), 113192 <https://doi.org/10.1016/j.socscimed.2020.113192>.

${ }^{21}$ George W. Burruss, Jennifer H. Peck, and Alesha L.J. Cameron, 'Fifty Years Post Gault: A MetaAnalysis of the Impact of Attorney Representation on Delinquency Outcomes', Journal of Criminal Justice, 66.November 2019 (2020), 101634 <https:/ / doi.org/10.1016/j.jcrimjus.2019.101634>.

${ }_{22}$ Camila H. Alvarez and Clare Rosenfeld Evans, 'Intersectional Environmental Justice and Population Health Inequalities: A Novel Approach', Social Science and Medicine, 269.December 2020 (2021), 113559 <https://doi.org/10.1016/j.socscimed.2020.113559>. 
number of instances where the Police, when conducting exams or arrests of suspects or perpetrators of crimes, always employ aspects of violence and even fail to adhere to the norms or procedures set forth in the Criminal Procedure Code. For instance, there is a money withdrawal at the time of detaining petty crime criminals, which is utilized to avoid the perpetrator having to be arrested and freed. Rather than bringing about justice, this may encourage the culprits who donate the money to become more active in committing a crime. The perpetrators of these crimes believe that by paying a few rupiahs, they will be absolved of all their misdeeds. ${ }^{23}$

The structural area is subdivided into the following subsystems within criminal justice. This is why this system must be completely synced with the criminal justice system's sub-system and with the structural field's subsystem as well. In this structural field, the sub-system is the sub-system that becomes the perpetrator or takes action to bring about justice. There are various further sub-systems within this structural field, including the Police, Prosecutors, Courts, and Correctional Institutions (Penitentiary). This structural field sub-system serves as the instrument and implementer for any regulatory infractions and acts that contravene applicable laws. As a result, it is necessary to develop correct synchronization in the material sector and in the structural field. ${ }^{24}$

Therefore, if a regulation is developed by the government, it should be compatible with the work required of law enforcers in the structural subsystem. However, what occurs in the enforcement and prosecution of criminals or those who violate the applicable laws and regulations in this structural field frequently does not correspond to the applicable legislation. Indeed, what is done with what is regulated by law is not always as it should be. Indeed, occasionally the converse occurs, namely the incompatibility of legal laws with the goals of law enforcement personnel seeking to achieve justice in society. The Criminal Procedure Code is not being implemented appropriately within law enforcement officials or in the structural field. ${ }^{25}$ To strengthen the efficacy of the Prosecutor's Office in enforcing the concept of opportunity, it is necessary to establish clear criteria for the requirements for deponering. This is done, of course, once the idea of public interest has been unified, in order to provide a uniform

${ }^{23}$ Matthew Hobbs and others, 'Investigating Change in the Food Environment over 10 Years in Urban New Zealand: A Longitudinal and Nationwide Geospatial Study', Social Science and Medicine, 269.November 2020 (2021), 113522 <https:/ / doi.org/10.1016/j.socscimed.2020.113522>. ${ }^{24}$ Judith Bom and Jannis Stöckel, 'Is the Grass Greener on the Other Side? The Health Impact of Providing Informal Care in the UK and the Netherlands', Social Science and Medicine, 269.December 2020 (2021) <https:// doi.org/10.1016/j.socscimed.2020.113562>.

${ }^{25}$ Karine Charry and Tina Tessitore, 'I Tweet, They Follow, You Eat: Number of Followers as Nudge on Social Media to Eat More Healthily', Social Science and Medicine, 269.December 2020 (2021), 113595 <https:// doi.org/10.1016/j.socscimed.2020.113595>. 
definition of public interest as the foundation for the Prosecutor's Office to prosecute a case. Thus, everybody in a position of decision-making will have the same view on when deponering should occur. ${ }^{26}$

\section{Cultural synchronization in Implementing the Principle of Opportunity by the Attorney General's Office.}

Cultural synchronization (cultural synchronization) is the concurrent and harmonious living of the values, attitudes, and philosophies that underpin the criminal justice system's entire operation. One of the subsystems that cannot be separated and is critical is the cultural subsystem. This sub-system demonstrates whether or not any of these justices may be realized. Synchronization in the structural sector is a community-based synchronization, as it is a synchronization of the culture or culture in society. We are all aware that Indonesian society is pluralistic, comprised of a diverse range of ethnic groups, ethnicities, and skin tones. Additionally, the majority of them have their own customary rules or regulations inside the community, which are recognized by the law in terms of their implementation within society. This is what occurs even when laws are written in such a way and are so beneficial. Even if law enforcement is deemed to be strong and fair by the government, if it is out of step with society's culture and customs, all efforts will be futile since there will be no laws that violate the companies that exist in society. ${ }^{27}$

This has likewise not been accomplished in the manner that it should have been. We may see that in the development of one of the government's recent laws, the Law on Pornography and Pornoaction. This law makes it clear that it regulates dress and even interaction. Even while we are well aware that in our beloved Indonesia, several tribes have traditional clothing that is quite revealing and even vulgar, particularly in the Papua region. With the passage of this law, the Indonesian people will never be prevented from wearing regional traditional clothes. Therefore, it is preferable to undertake a survey and further research prior to enacting legislation to ensure adequate synchronization within the criminal justice subsystem. ${ }^{28}$

${ }^{26}$ Ha Neul Yim, Jordan R. Riddell, and Andrew P. Wheeler, 'Is the Recent Increase in National Homicide Abnormal? Testing the Application of Fan Charts in Monitoring National Homicide Trends over Time', Journal of Criminal Justice, 66.November 2019 (2020), 101656 <https://doi.org/10.1016/j.jcrimjus.2019.101656>.

27 Richard K. Moule, 'Under Siege?: Assessing Public Perceptions of the "War on Police"', Journal $\begin{array}{lllll}\text { of Criminal } \quad J u s t i c e, & \text { 66.October } & 2019 & \text { (2020), } & 101631\end{array}$ <https://doi.org/10.1016/j.jcrimjus.2019.101631>.

${ }^{28}$ Lindsay Leban and Chris L. Gibson, 'The Role of Gender in the Relationship between Adverse Childhood Experiences and Delinquency and Substance Use in Adolescence', Journal of Criminal Justice, 66.October 2019 (2020), 101637 <https:/ / doi.org/10.1016/j.jcrimjus.2019.101637>. 
Cultural synchronization is a necessary and integral component of the cultural field. This sub-system demonstrates whether or not any of these justices may be realized. Synchronization in the cultural field is a process that must be community-based. This cultural synchronization is a societal synchronization of culture or culture. Concerning the Prosecutor's Office's application of deponering as a principle of opportunity, the public believes that it is not regulated what cases can be ruled out. The public interest, as defined in the RI Attorney's Law, reduces public confidence in the Attorney General's decision to dismiss or defer criminal charges. In the interest of the public. After establishing a clear definition of the public interest, the Attorney General's Decision to Set Aside Cases for the Public Interest must be genuinely accepted by the community, with no adverse consequences. ${ }^{29}$

Therefore, the Attorney General's performance of his duties and authorities requires careful consideration not only of advice and opinions from state power agencies, but also of supervision and a sound system for implementation, such as conducting public education about its policies for setting aside cases in the public interest, as well as providing an explanation of the factors considered in excluding possible outcomes. Criminal or delinquent behavior in the public interest If this is done effectively, the Attorney General's implementation of setting aside cases in the public interest pursuant to the Republic of Indonesia's Law on the Prosecutor's Office will be more effective for the community. ${ }^{30}$

\section{Conclusion}

Based on the results of the discussion above, it can be concluded that, the optimization of the Deponering function as part of the opportunity principle is accomplished by Substance Synchronize, specifically by clarifying the concept of public interest that serves as the foundation for Deponering implementation. The concept of public interest should encompass State Interests, Community Interests, and Personal Interests, with distinct bounds to ensure that deponering can be conducted within defined parameters. Additionally, in the area of structural synchronization, in the form of providing parameters to the Prosecutor's Office as a guide in implementing deponering in order to create legal certainty regarding when deponering must be carried out, as well as a control system for deponering performance; and Cultural Synchronization, in the form of providing understanding and socialization to the community in order to increase public confidence in the implementation of the opportunity principle;

${ }^{29}$ Jill Owczarzak and others, “"You're Nobody without a Piece of Paper:” Visibility, the State, and Access to Services among Women Who Use Drugs in Ukraine', Social Science and Medicine, 269.November 2020 (2021), 113563 <https:/ / doi.org/10.1016/j.socscimed.2020.113563>.

${ }^{30}$ Moule. 


\section{Refrences}

Alvarez, Camila H., and Clare Rosenfeld Evans, 'Intersectional Environmental Justice and Population Health Inequalities: A Novel Approach', Social Science and Medicine, 269.December 2020 (2021), 113559 <https://doi.org/10.1016/j.socscimed.2020.113559>

Bom, Judith, and Jannis Stöckel, 'Is the Grass Greener on the Other Side? The Health Impact of Providing Informal Care in the UK and the Netherlands', Social Science and Medicine, 269.December 2020 (2021) <https://doi.org/10.1016/j.socscimed.2020.113562>

Burruss, George W., Jennifer H. Peck, and Alesha L.J. Cameron, 'Fifty Years Post Gault: A Meta-Analysis of the Impact of Attorney Representation on Delinquency Outcomes', Journal of Criminal Justice, 66. November 2019 (2020), 101634 <https://doi.org/10.1016/j.jcrimjus.2019.101634>

Charry, Karine, and Tina Tessitore, 'I Tweet, They Follow, You Eat: Number of Followers as Nudge on Social Media to Eat More Healthily', Social Science and Medicine, 269.December $2020 \quad$ (2021), 113595 <https://doi.org/10.1016/j.socscimed.2020.113595>

Connolly, Eric J., Eric M. Cooke, Kevin M. Beaver, and Wyatt Brown, 'Do Developmental Changes in Impulsivity and Sensation Seeking Uniquely Predict Violent Victimization? A Test of the Dual Systems Model', Journal of Criminal Justice, 66.October $2019 \quad$ (2020), 101639 <https://doi.org/10.1016/j.jcrimjus.2019.101639>

Das, Abhery, Parvati Singh, Anju K. Kulkarni, and Tim A. Bruckner, 'Emergency Department Visits for Depression Following Police Killings of Unarmed African Americans', Social Science and Medicine, 269.November 2020 (2021), 113561 <https://doi.org/10.1016/j.socscimed.2020.113561>

Dian, Resti, and Suviwat Jenvitchuwong, 'Implementation of Halal Product Assurance in the Pharmaceutical Sector in Indonesia', Journal of Human Rights, Culture and Legal System, 1.3 (2021), 164-79 <https://doi.org/https://doi.org/10.53955/jhcls.v1i3.19>

Ellison, Jared M., and Randy Gainey, 'An Opportunity Model of Safety Risks among Jail Officers', Journal of Criminal Justice, 66. October 2019 (2020), 101632 <https://doi.org/10.1016/j.jcrimjus.2019.101632>

Fooken, Jonas, and Linh K. Vo, 'Exploring the Macroeconomic and Socioeconomic Determinants of Simultaneous over and Undernutrition in Asia: An Analysis of Stunted Child - Overweight Mother Households', Social Science and Medicine, 269.December 2020 (2021), 113570 <https:/ / doi.org/10.1016/j.socscimed.2020.113570>

Ford, Jason A., Corey R. Pomykacz, Kasim Ortiz, Sean Esteban McCabe, and Ty S. Schepis, 'Educational Attainment and Prescription Drug Misuse: The Importance of Push and Pull Factors for Dropping Out', Journal of Criminal 
$\begin{array}{llll}\text { Justice, } & \text { 66.October } & 2019 & \text { (2020), }\end{array}$ <https:// doi.org/10.1016/j.jcrimjus.2019.101636>

Hall, Brian J., Lei Huang, Grace Yi, and Carl Latkin, 'Fast Food Restaurant Density and Weight Status: A Spatial Analysis among Filipina Migrant Workers in Macao (SAR), People's Republic of China', Social Science and Medicine, 269.July $2020 \quad$ (2021), 113192 <https:// doi.org/10.1016/j.socscimed.2020.113192>

Harms, Philipp, and Jakob Schwab, 'Depression of the Deprived or Eroding Enthusiasm of the Elites: What Has Shifted the Support for International Trade?', European Journal of Political Economy, 64.November 2019 (2020), 101901 <https:// doi.org/10.1016/j.ejpoleco.2020.101901>

Hobbs, Matthew, Joreintje Dingena Mackenbach, Jesse Wiki, Lukas Marek, Geraldine F.H. McLeod, and Joseph M. Boden, 'Investigating Change in the Food Environment over 10 Years in Urban New Zealand: A Longitudinal and Nationwide Geospatial Study', Social Science and Medicine, 269.November $2020 \quad$ (2021), 113522 <https://doi.org/10.1016/j.socscimed.2020.113522>

Iqra, Moh, Syabani Korompot, and Al-fatih David, 'The Principle of Equality Before the Law in Indonesian Corruption Case : Is It Relevant?', Journal of Human Rights, Culture and Legal System, 1.3 (2021), 135-46

Leban, Lindsay, and Chris L. Gibson, 'The Role of Gender in the Relationship between Adverse Childhood Experiences and Delinquency and Substance Use in Adolescence', Journal of Criminal Justice, 66.October 2019 (2020), 101637 <https:// doi.org/10.1016/j.jcrimjus.2019.101637>

McNamara, Simon, Aki Tsuchiya, and John Holmes, 'Does the UK-Public's Aversion to Inequalities in Health Differ by Group-Labelling and HealthGain Type? A Choice-Experiment', Social Science and Medicine, 269.December 2020 (2021), 113573 <https:// doi.org/10.1016/j.socscimed.2020.113573>

Mishra, Utkarsh K, and Abhishek Negi, 'Should Trade Remedies Be Eliminated from WTO : A Response to Tania Voon', Journal of Human Rights, Culture and Legal System, 1.3 (2021), 194-200

Moule, Richard K., 'Under Siege?: Assessing Public Perceptions of the "War on Police"', Journal of Criminal Justice, 66.October 2019 (2020), 101631 <https://doi.org/10.1016/j.jcrimjus.2019.101631>

Oktora, Arif Purnama, and Hilaire Tegnan, 'Strategy for Implementing Operations to Handle the Crime of Narcotics', Journal of Human Rights, Culture and Legal System, 1.3 (2021), 201-13

Owczarzak, Jill, Asiya K. Kazi, Alyona Mazhnaya, Polina Alpatova, Tatyana Zub, Olga Filippova, and others, "YYou're Nobody without a Piece of Paper:" Visibility, the State, and Access to Services among Women Who Use Drugs in Ukraine', Social Science and Medicine, 269.November 2020 (2021), 113563 <https://doi.org/10.1016/j.socscimed.2020.113563> 
Potrafke, Niklas, Marcus Rösch, and Heinrich Ursprung, 'Election Systems, the "Beauty Premium" in Politics, and the Beauty of Dissent', European Journal of Political Economy, 64.October 2019 <https://doi.org/10.1016/j.ejpoleco.2020.101900>

(2020)

Rima, Dzhansarayeva, Malikova Sholpan, Atakhanova Gulzagira, Bisenova Meruert, and Kevin M. Beaver, 'Exploring the Potential Association between Gang Membership and Health Outcomes in a Longitudinal Sample of Youth and Young Adults', Journal of Criminal Justice, 66.May 2019 (2020), 101629 <https://doi.org/10.1016/j.jcrimjus.2019.101629>

Rocca, Corinne H., Heidi Moseson, Heather Gould, Diana G. Foster, and Katrina Kimport, 'Emotions over Five Years after Denial of Abortion in the United States: Contextualizing the Effects of Abortion Denial on Women's Health and Lives', Social Science and Medicine, 269.November 2020 (2020), 113567 <https://doi.org/10.1016/j.socscimed.2020.113567>

Shjarback, John A., and Justin Nix, 'Considering Violence against Police by Citizen Race/Ethnicity to Contextualize Representation in Officer-Involved Shootings', Journal of Criminal Justice, 66.October 2019 (2020), 101653 <https://doi.org/10.1016/j.jcrimjus.2019.101653>

Sofiana, Ratna, Satria Utama, and Abdur Rohim C, 'The Problems of Halal Certification Regarding Consumer Protection in Malaysia and Indonesia', Journal of Human Rights, Culture and Legal System, 1.3 (2021), 180-93 <https:// doi.org/https:// doi.org/10.53955/jhcls.v1i3.16>

Vijayasingham, Lavanya, Uma Jogulu, and Pascale Allotey, 'Ethics of Care and Selective Organisational Caregiving by Private Employers for Employees with Chronic Illness in a Middle-Income Country', Social Science and $\begin{array}{lll}\text { Medicine, } & \text { 269.December } 2020 \quad \text { (2021), } & 113608\end{array}$ <https://doi.org/10.1016/j.socscimed.2020.113608>

de Vries, Ieke, Amy Farrell, Vanessa Bouché, and Dana E. Wittmer-Wolfe, 'Crime Frames and Gender Differences in the Activation of Crime Concern and Crime Responses', Journal of Criminal Justice, 66.November 2019 (2020), 101651 <https://doi.org/10.1016/j.jcrimjus.2019.101651>

Wang, Zhicheng, Lisa Bero, and Quinn Grundy, 'Understanding Professional Stakeholders' Active Resistance to Guideline Implementation: The Case of Canadian Breast Screening Guidelines', Social Science and Medicine, 269.December 2020 <https://doi.org/10.1016/j.socscimed.2020.113586>

Yim, Ha Neul, Jordan R. Riddell, and Andrew P. Wheeler, 'Is the Recent Increase in National Homicide Abnormal? Testing the Application of Fan Charts in Monitoring National Homicide Trends over Time', Journal of Criminal Justice, 66.November 2019 <https://doi.org/10.1016/j.jcrimjus.2019.101656> 